\title{
Cognitive approach to translation and interpreting teaching methods
}

Julia Levi

Department of the English, MGIMO University, Russia

https://doi.org/10.36505/ExLing-2016/07/0020/000279

\begin{abstract}
Nowadays translation/interpreting studies are focused upon human mental processes, cognition, the role of the interpreter/translator. According to the human activity theory, each action is purpose - oriented, thus a complex act of translation/interpreting which can be described as a secondary process of human activity is goal - oriented as well. It means that the act of interpreting/ translation corresponds to the main principles of human activity, has its own purpose and is aimed at achieving the same result as an ordinary act of communication, i.e. a communication effect. We believe, it is critical to start an account of the text for translation purposes by making a deliberate pre-translation text analysis (PTA), which according to most experts, may consist of several activities.
\end{abstract}

Key words: cognition, the act of interpreting/ translation, pre-translation text analysis

\section{Introduction}

A new paradigm of language studies allowed linguists in the late XX early XXI centuries to consider the language as a dynamic phenomenon, rather than a static product, so nowadays experts in translation/ interpreting studies have become more interested in exploring the basic principles of the process of translation/interpreting, which is characterized by the shift to the study of human mental processes, cognition, the role of the interpreter/translator. At the first stage of the development of translation/interpreting science scholars focused on the analysis and description of some objective laws and rules of transformations. But later a new approach with the focus on the nature of the process of translation/interpreting was put forward, which became possible due to advancement in research in the fields of psycholinguistics, sociolinguistics, cognitive linguistics, anthropology, and etc. The roots of a cognitive approach can be traced back to the ideas of such renowned linguists as F. de Saussure, L. Vigotskyi, L. Sherba, A. N. Leontiev, A. A. Leontiev, and many others. In fact they developed and implemented the strategies of linguistic studies which consider the language as a part of human activity with a human playing the central role in it. According to the human activity theory, each action is purpose - oriented, thus a complex act of translation/interpreting

ExLing 2016: Proceedings of $7^{\text {th }}$ Tutorial and Research Workshop on Experimental Linguistics, 27 June - 2 July 2016, Saint Petersburg, Russia 
which can be described as a secondary process of human activity is goal oriented as well. It means that the act of interpreting/ translation corresponds to the main principles of human activity, has its own purpose and is aimed at achieving the same result as an ordinary act of communication, i.e. a communication effect.

What allows translators/interpreters to achieve the same communication effect, evoke the same feelings and emotions in the target recipient? We believe that a profound comprehension of the original text, successful meaning construction produces a communication effect envisaged by the author of the original text.

\section{Methodology}

According to J. Field, central to meaning construction is the distinction between 1) the words on the page or in the ear; 2) the propositional information that a text contains (loosely, its literal meaning); and 3) the enriched and selective interpretation which a reader or listener takes away. In processing a text, a comprehender performs a number of operations. At a sentence level they 1) extract propositional information; 2) make any necessary inferences; 3) enrich the interpretation by applying word knowledge; 3) integrate the new information into their mental representation of the text so far; 4) monitor their comprehension in case of misunderstanding.

At discourse level, they also have 1) to recognize the hierarchical structure of the text; 2) identify patterns of logic which link the parts of the text; 3) determine which parts of the text are important to the speaker/writer or relevant to their own purposes.

Numerous accounts of discourse comprehension which attempt to describe how text information is built into an overall meaning representation have proved to be useful both for scholars and learners. A cognitive approach to text studies help linguists perceive information processing mechanisms better and therefore work out some strategies to secure a full understanding of the text.

Nevertheless, comprehension is one of the stages that the model of translation/interpreting comprises. In fact, the model consists of three stages: comprehension, the act of translation/interpreting, and text production.

At the level of comprehension the translator/interpreter builds the concept of the text. When they perceive the original text in a foreign language, they search for semantic frame equivalents to their knowledge. Charles Fillmore believes that, "meanings are relativized to scenes". According to him, meanings have an internal structure which is 
determined relative to a background frame or a scene. What is more, during the text processing a so-called process of anticipation plays an important role as it helps to predict the final unfolding of the text through the explanation of dynamic sematic frames. It goes without saying that anticipation is critically important in simultaneous interpretation.

At the level of translation/interpreting the translator/interpreter builds dynamic frames in his/her mind on the basis of the original text and relates them to their frame equivalents in the target language. They find prototype equivalents on the basis of prototype semantic frame structures and try to find a solution if they are missing, in which case, they apply a certain strategy to compensate for them.

At the final stage the translator/interpreter produces a text in a foreign language taking into account all its syntactic features.

Successful translation/interpreting requires a profound comprehension of the original text, retrieval of adequate equivalents corresponding to dynamic frames and scenes, and finally a text production in a target language. Therefore, from the perspective of a cognitive approach, the role of the translator/interpreter and the text remains the major focus of linguists' attention. Many scholars believe that the translator/interpreter performs the role of a reader, analyst, linguist, text creator, editor and, finally critic of it. But the text still needs a thorough examination, especially in terms of a pre-translation analysis in a written activity which helps work out and apply special translation strategies.

\section{Results}

Most experts suggest that a pre-translation text analysis (PTA) may consist of several activities: 1) considering factors external to the linguistic text; 2) establishing the style and genre of the text; 3) designating the type of the information represented in the text. The succession of these stages may vary, but all the existing models of PTA illustrate 1) textocentric (linguistic); 2) functional; 3) communicative approaches to this process.

On the basis of the U. Breus and N. Valeeva conceptions of PTA, we present a full PTA, which ensures a better comprehension of the text and a well-balanced approach to the selection of a translation strategy. 
Identify the type of the text (narration, description, etc.) and its functional style (scientific, publicist, official, colloquial, etc.).

Outline the basic communication goal of the author, his/her intention, cultural/situational factors.

Specify the primary and secondary functions of the text (to inform, communicate, exert influence), which can be understood through explicit or implicit markers.

Outline the context.

Define the main topic of the text.

Specify the stylistic devices of the author.

Identify the examples of cultural dissimilarities, which are evident in the text, and make predictions concerning potential difficulties the translator might confront.

According to the type of difficulties choose a variant of translation (find the logical focus of the sentence, generalization, specification, logical development, the shift of focus, etc.)

\section{Conclusion}

A cognitive approach has proved to be efficient in translation/interpreting teaching methodology as it explains the cognitive functions of the humans' mind, provides a profound analysis of the translation/interpreting model, through a well elaborated pretranslation analysis (PTA) helps learners apply the right strategy of translation, and thus, master the art of translation/interpreting.

\section{References}

Alekseeva, I.S. 2004. Vvedenie v perevodovedenie. - M.: Izd. centr «Akademiya».

Breus, E.V. 2007. Kurs perevoda s anglijskogo yazyka na russkij. Uchebnoe posobie. M.: Valent.

Field, J. 2004. Psycholionguistics The key concepts, Routedge Taylor \& Francis Group: London and New York.

Fillmore, C. 1977. The case for case reopened. In Syntax and Semantics 8: Grammatical Relations, ed. P. Cole, 59 - 81. New York: Academic Press.

Nefedova L.A., Remhe I. N. Kognitivnye osobennosti perevodcheskogo processa. Chelyabinskij gosudarstvennyj universitet. - S. 64-72

Shvejcer A.D. Teoriya perevoda (status, problemy, aspekty).

Valeeva, N.G. 2010. Teoriya perevoda: kul'turno-kognitivnyj i kommunikativnofunkcional'nyj aspekty: Monografiya. - M.: RUDN.

Zimnyaya, I.A. 2001. Lingvopsihologiya rechevoj deyatel'nosti. - M.: Moskovskij psihologo-social'nyj institut, Voronezh: NPO «MODEHK». (Seriya «Psihologi Otechestva»). 